\title{
Teaching NeuroImages: Useless (and restless) hand of Oppenheim in multiple sclerosis
}

Daniel Ferreira, MD, Daniela Ferro, MD, Guilherme Bastos, MD, and Madalena Pinto, MD

Neurology ${ }^{\circledR}$ 2020;95:e2043-e2044. doi:10.1212/WNL.0000000000010261

Figure 1 Patient holding the arms outstretched

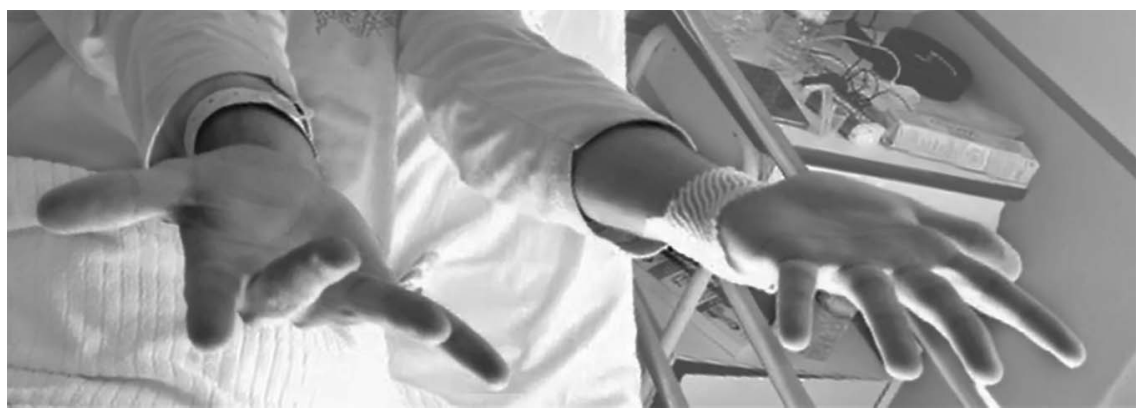

Pseudoathesosis of the right hand with writhing movements of the fingers exacerbated during eyes closure.

A 23-year-old man presented a 2-week history of progressive loss of dexterity and incoordination in his right hand together with ipsilateral occipito-cervical paresthesia. In addition, he reported a feeling of discomfort and an urge to move his fingers at rest. Pseudoathetosis (figure 1) and reduced joint position and vibration senses were consistent with the useless hand description of Oppenheim. ${ }^{1}$

MRI scan was suggestive of multiple sclerosis (MS; figure 2), depicting an active demyelinating lesion in right dorsal cervical spinal cord.

Figure 2 Brain and spinal cord MRI

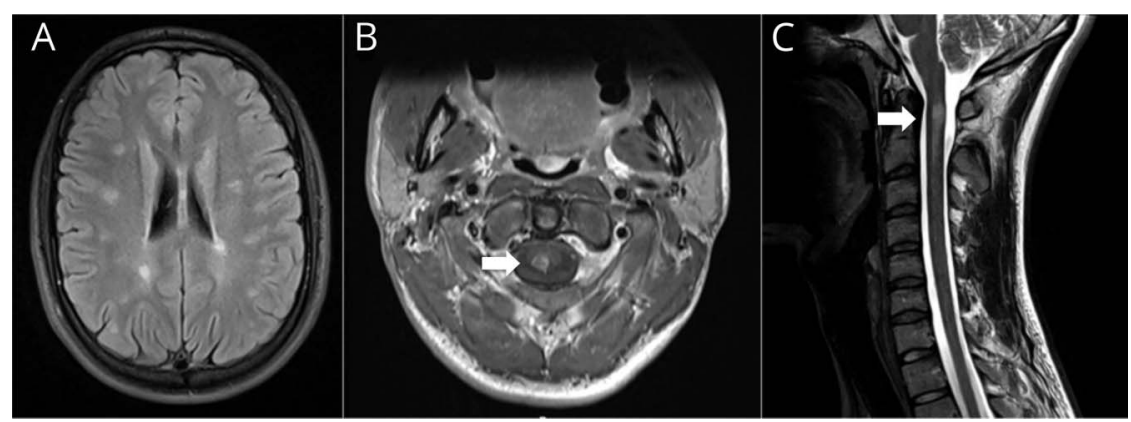

Axial T2-fluid-attenuated inversion recovery (A) demonstrates multiple demyelinating brain lesions; axial contrast-enhanced T1 (B) and sagittal T2 (C) show an active demyelinating lesion at the C1 level in the posterior spinal cord (arrows).

\section{Correspondence}

Dr. Ferreira

daniel.of321@gmail.com

\section{MORE ONLINE}

$\rightarrow$ Teaching slides

links.lww.com/WNL/

B165

From the Departments of Neurology (D. Ferreira, D. Ferro, M.P.) and Neuroradiology (G.B.), Centro Hospitalar Universitário de São João, EPE, Porto; and the Department of Clinic Neurosciences and Mental Health (D. Ferreira, D. Ferro), Medical Faculty of Porto University, Portugal.

Go to Neurology.org/N for full disclosures. Funding information and disclosures deemed relevant by the authors, if any, are provided at the end of the article. 
Restless legs syndrome has been described in $\mathrm{MS}^{2}$ and similar symptomatology can be present in the upper limbs during an MS relapse.

\section{Study funding}

No targeted funding reported.

\section{Disclosure}

The authors report no disclosures relevant to the manuscript. Go to Neurology.org/N for full disclosures.

\section{Appendix Authors}

\begin{tabular}{lll}
\hline Name & Location & Contribution \\
\hline Daniel & Centro Hospitalar & Design, concept, and draft of \\
Ferreira, & Universitário de São João, & the manuscript \\
MD & EPE, Porto, Portugal & \\
\hline
\end{tabular}

Appendix (continued)

\begin{tabular}{lll}
\hline Name & Location & Contribution \\
\hline $\begin{array}{l}\text { Daniela } \\
\text { Ferro, MD }\end{array}$ & $\begin{array}{l}\text { Centro Hospitalar } \\
\text { Universitário de São João, } \\
\text { EPE, Porto, Portugal }\end{array}$ & $\begin{array}{l}\text { Provided significant input for } \\
\text { early and final drafts of the } \\
\text { manuscript }\end{array}$ \\
\hline $\begin{array}{l}\text { Guilherme } \\
\text { Bastos, MD }\end{array}$ & $\begin{array}{l}\text { Centro Hospitalar } \\
\text { Eniversitário de São João, } \\
\text { EPE, Porto, Portugal }\end{array}$ & $\begin{array}{l}\text { Interpretation of the data and } \\
\text { provided significant input for } \\
\text { early and final drafts of the } \\
\text { manuscript }\end{array}$ \\
$\begin{array}{l}\text { Madalena } \\
\text { Pinto, MD }\end{array}$ & $\begin{array}{l}\text { Centro Hospitalar } \\
\text { Eniversitário de São João, }\end{array}$ & $\begin{array}{l}\text { Manuscript design, } \\
\text { supervision and critical } \\
\text { revision of manuscript }\end{array}$ \\
\hline
\end{tabular}

\section{References}

1. Oppenheim H. Discussion on the different types of multiple sclerosis. Br Med J 1911: 729-733.

2. Italian REMS Study Group, Manconi M, Ferini-Strambi L, Filippi M, et al. Multicenter case-control study on restless legs syndrome in multiple sclerosis: the REMS study. Sleep 2008;31:944-952. 


\section{Neurology}

Teaching NeuroImages: Useless (and restless) hand of Oppenheim in multiple sclerosis

Daniel Ferreira, Daniela Ferro, Guilherme Bastos, et al.

Neurology 2020;95;e2043-e2044 Published Online before print July 9, 2020

DOI 10.1212/WNL.0000000000010261

This information is current as of July 9, 2020

$\begin{array}{ll}\begin{array}{l}\text { Updated Information \& } \\ \text { Services }\end{array} & \begin{array}{l}\text { including high resolution figures, can be found at: } \\ \text { http://n.neurology.org/content/95/14/e2043.full }\end{array} \\ \text { References } & \text { This article cites } 1 \text { articles, } 0 \text { of which you can access for free at: } \\ \text { http://n.neurology.org/content/95/14/e2043.full\#ref-list-1 } & \text { This article, along with others on similar topics, appears in the } \\ \text { following collection(s): } & \text { MRI } \\ \text { http://n.neurology.org/cgi/collection/mri } & \text { Multiple sclerosis } \\ & \text { http://n.neurology.org/cgi/collection/multiple_sclerosis } \\ & \text { Restless legs syndrome } \\ & \text { http://n.neurology.org/cgi/collection/restless_legs_syndrome } \\ & \text { Information about reproducing this article in parts (figures,tables) or in } \\ & \text { its entirety can be found online at: } \\ & \text { http://www.neurology.org/about/about_the_journal\#permissions } \\ & \text { Information about ordering reprints can be found online: } \\ \text { Permissions \& Licensing } & \text { http://n.neurology.org/subscribers/advertise }\end{array}$

Neurology ${ }^{\circledR}$ is the official journal of the American Academy of Neurology. Published continuously since 1951, it is now a weekly with 48 issues per year. Copyright () 2020 American Academy of Neurology. All rights reserved. Print ISSN: 0028-3878. Online ISSN: 1526-632X.

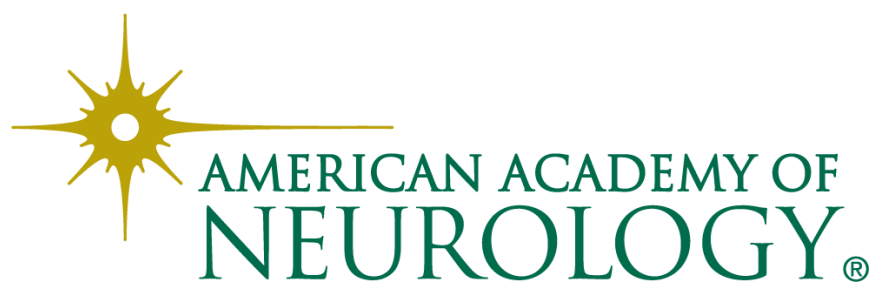

